\title{
Differential Effect of Fertilizers on Menthol Contents in Mint (Mentha Arvensis)
}

\author{
Muhammad Izhar, Muhammad khan¹, Dr Tahira Yasmin, Najma Yousaf Zahid
}

\begin{abstract}
Mint either as herb or its essential oil form is used for flavoring, perfume production and medicinal purposes. Among various factors affecting mint plant, type and amount of fertilizers, such as nitrogen based, have more pronounced effect on mint plants growth and quantity and quality of menthol oil. Therefore, the present study was conducted with to evaluate the effect of fertilizer on menthol contents and to observe the accurate doses of fertilizer for the maximum quantity of menthol content in mint. Seven treatments of fertilizers $(\mathrm{T} 1=\mathrm{Control}$, T2=FYM 20 t/ha, T3=N, P, K 75:15:15 kg/ha and FYM 15 t/ha, T4=N, P, K 100:30:30 kg/ha and FYM 10 t/ha, T5=N, P, K 150:45:45 kg/ha and FYM 8 t/ha, T6=N, P, K 175:50:50 kg/ha and FYM 6 t/ha and T7=N, P, K 225:60:60 kg/ha and No FYM) were applied randomly in each block with three replications. Result demonstrated that plant height was maximum with $\mathrm{T} 7$ while no.of leaves, leaf area, herb yield and oil yield with T5 and menthol contents was maximum with T6.
\end{abstract}

Keywords: Combined fertilizer, Oil yield, Menthol contents

\section{INTRODUCTION}

Mint is the common name of Mentha arvensis having approximately 25 species of the genus Mentha belonging to family Lamiaceae. Different species of the family Lamiaceae have been cultivated occur in different parts of the world with major producers of mint are India, China, Vietnam, and Brazil (Chand et al., 2004; Clark, 1998; Kumar et al., 2000; Lawrence, 2007; Singh and Saini, 2008). Different mint species often contains 40-85\% menthol as major constituent. The mint species Mentha piperita known as American peppermint contain 50-55\% and Mentha arvensis termed as Japanese mint have 80-85\% menthol contents (Ozguven and Kirici, 1999).

In Pakistan, unfortunately mint is cultivated only in northern parts of Punjab and NWFP (Shinwari et al., 2004). A limiting factor for low production in Pakistan is due to lack of sufficient information on agronomics and post harvest management of this crop. Therefore, Pakistan imports large quantity of mint to fulfill internal consumption of mint and demand for menthol and mint oil.

Mint either as herb or its essential oil form is used for flavoring, perfume production and medicinal purposes (Dorman et al., 2003). Mint is valued for its multipurpose uses in the field of pharmaceuticals, cosmetics as well as for flavoring foods beverages and tobacco (Ohloff, 1994). It is also used in oral products e.g. tooth paste and mouth fresheners due to its physiological cooling effect. Moreover, essential oil and their valuable chemical constituents obtained from menthol mint have great export potential. Higher essential oil content and better quality of oil will give higher production and more output to the producers.

The impact of environmental factors such as temperature, relative humidity, irradiance, photoperiod, fertilizer application and cultivation practices influence the growth and yield of mint plants which resulted in change in composition of essential oil menthol. Furthermore, type and amount of fertilizers, such as nitrogen based, have more pronounced effect on mint plants growth and quantity and quality of menthol oil. However, little work has been done on optimizing levels of fertilizer application for maximizing the herb, oil yield and qualities of oil of different cultivars being commercially cultivated in different parts of the world (Patra, 2008).

Since mint is a heavy feeder of plant nutrients and takes up substantial quantities of N, P and K (Yadav et al., 1983, Patra et al., 2002). Furthermore, it is mostly grown in light textured soils, so efficiency of $\mathrm{N}$ fertilizer is sometimes very low. In order to improve the efficiency of $\mathrm{N}$ fertilizers in mint plants, several scientists are still working on various methods. Application of nitrification inhibitors with urea (Ram et al., 1996), Nimin and dicyandiamide coated over plin urea (Patra et al., 2002), plant growth regulators (Kewalanand et al., 1998), mulching (Patra et al., 1993) and use of organic fertilizers (Chand et al., 2001) significantly increased herb and oil yields in menthol mint.

\footnotetext{
${ }^{1}$ Corresponding Author: muhammadkhan1979@gmail.com
} 
Moreover, combined applications of fertilizer and organic residues have greater affect on improved mint oil yield (Patra et al., 2000; Chand et al., 2001). The application of farm yard manure (FYM) before the planting of mint suckers produce a beneficial effect on crop growth (Chand et al., 2004). Because of their availability and capacity to supply macro as well as micronutrients, the farm yard manure, farm residues and other organic materials can supplement the nutritional requirements of the mint plants. However, few scientists have been work for combined used of inorganic and organic fertilizers for oil yields in menthol mint. Keeping in view the above mentioned facts, the present study was conducted with to evaluate the effect of fertilizer on menthol contents and to observe the accurate doses of fertilizer for the maximum quantity of menthol content in mint.

\section{Materials AND Methods}

The experiment was conducted to evaluate the effect of different doses of fertilizer on menthol contents in mint during 2009-10 in the field area of Department of Horticulture, Pir Mehr Ali Shah Arid Agriculture University Rawalpindi, and with the collaboration of National Agricultural Research Centre (NARC).

In each sub-block, 15 mint seedlings of about 20 days old were transplanted in Randomized Complete Block Design (RCBD). Transplanting was done by maintaining inter row distance of $45 \mathrm{~cm}$ and intra row distance of $15 \mathrm{~cm}$. Seven treatments of fertilizers $(\mathrm{T} 1=$ Control, T2=FYM 20 t/ha, T3=N, P, K 75:15:15 kg/ha and FYM 15 t/ha, T4=N, P, K 100:30:30 kg/ha and FYM 10 t/ha, T5=N, P, K 150:45:45 kg/ha and FYM 8 t/ha, T6=N, P, K 175:50:50 kg/ha and FYM 6 t/ha and T7=N, P, K 225:60:60 kg/ha and No FYM) were applied randomly in each block with three replications. Nitrogen was applied in the form of urea in three equal splits, i.e. at transplanting, 30 and 45 days after transplanting. Full doses of $\mathrm{P}$ in the form of single super phosphate (SSP), K as sulphate of potash (SOP) and farm yard manure (FYM) were applied at the time of transplanting. During crop growth period three irrigations were applied when required. All the recommended cultural practices of irrigation, weeding, fertilizer mixing, etc. were followed as per requirement during the growth period. Data presented in (Table 1) indicates the physio-chemical properties of soil used in this experiment. At crop maturity, data regarding morphological characteristics i.e. plant height, No. of leaves per plant, leaves area were recorded. Mint plants were harvested at physiological maturity. Fresh whole herb (leaves, floral parts and new branches) about $1 \mathrm{~kg}$ was subjected to steam distillation process and essential oil obtained was weighted. The extracts obtained from steam distillation process were subjected to Gas Chromatography-Mass Spectrometry (GC-MS) to determine menthol contents. GC-MS data were obtained on a Perkin-Elmer mass spectrometer using a PE-5 column $(30 \mathrm{~m}$. $0.32 \mathrm{~mm}$ i.d., film thickness $0.25 \mu \mathrm{m})$. The carrier gas was helium and the temperature programming was $5 \mathrm{~min}$ at $70{ }^{\circ} \mathrm{C}$, rising at $2^{\circ} \mathrm{C} / \mathrm{min}$ to $120^{\circ} \mathrm{C}$, then at $3{ }^{\circ} \mathrm{C} / \mathrm{min}$ to $240{ }^{\circ} \mathrm{C}$. The data obtained in response to treatments was computed following ANOVA technique and DMR test was applied to differentiate the treatment differences (Steel et al., 1997) using Statistics' Version 9 computer software package.

\section{RESULTS AND DISCUSSION}

Data presented in Table 2 showed that combined applications of different doses of NPK fertilizers and FYM significantly improved the plant height in mint plants, No. of leaves per plant and leaves area. Results demonstrated that maximum plant height was observed $42.5 \mathrm{~cm}$ in T7 where NPK were applied 225:60:60 kg/ha and No FYM while minimum was found $35.4 \mathrm{~cm}$ in T2 where FYM was applied $20 \mathrm{t} / \mathrm{ha}$ as shown in table 2. However, maximum No. of leaves per plant (181) and leaves area $\left(12.4 \mathrm{~cm}^{2}\right)$ were recorded with T5 where NPK was applied 150:45:45 $\mathrm{kg} / \mathrm{ha}$ and FYM 8 t/ha while minimum with T0 where no fertilizer and FYM applied as shown in table 2.

It is fact that nitrogen $(\mathrm{N})$ is very essential for plant growth because it is a main constituents of proteins, nucleic acid, certain hormones and chlorophyll, which are all important for plant growth (Hopkins, 1997). Phosphorous (P) like nitrogen is equally important for plant growth and found largely as phosphate esters which plays an important role in photosynthesis and intermediate metabolism. Further, it is a main component of nucleic acid and phospholipids (Weier et al., 1982). Hopkins (1997) explained the role of potassium (K), which involved activation of several enzymes acted in photosynthesis and respiration along with its function in osmoregulation. 
Table3.1. Properties of soils used for experiment

\begin{tabular}{|c|c|c|}
\hline Parameter & Unit & Value \\
\hline Textural class & -- & Sandy loam \\
\hline Sand & $\%$ & 54 \\
\hline Silt & י & 34 \\
\hline Clay & $"$ & 12 \\
\hline $\mathrm{pH}_{\mathrm{s}}$ & "י & 7.8 \\
\hline $\mathbf{E C}_{\mathrm{e}}$ & $\mathrm{dS} \mathrm{m}^{-1}$ & 0.35 \\
\hline Organic matter & $\%$ & 0.39 \\
\hline $\mathrm{N}-\mathrm{NO}_{3}$ & $\mu \mathrm{g} \mathrm{g}^{-1}$ & 11.2 \\
\hline Available $\mathbf{P}$ & $\mu \mathrm{g} \mathrm{g}^{-1}$ & 4.5 \\
\hline Available K & $\mu \mathrm{g} \mathrm{g}^{-1}$ & 124 \\
\hline
\end{tabular}

Table2

\begin{tabular}{|l|l|l|l|}
\hline Treatment & Plant Height $(\mathbf{c m})$ & No.of Leaves & Leaf Area (cm2) \\
\hline T1 & $36.2 \mathrm{D}$ & $79 \mathrm{E}$ & $9.4 \mathrm{~B}$ \\
\hline T2 & $35.4 \mathrm{D}$ & $121 \mathrm{D}$ & $10.0 \mathrm{~B}$ \\
\hline T3 & $39.0 \mathrm{C}$ & $147 \mathrm{C}$ & $10.1 \mathrm{~B}$ \\
\hline T4 & $38.0 \mathrm{C}$ & $165 \mathrm{~B}$ & $9.5 \mathrm{~B}$ \\
\hline T5 & $40.5 \mathrm{~B}$ & $181 \mathrm{~A}$ & $12.4 \mathrm{~A}$ \\
\hline T6 & $41.4 \mathrm{AB}$ & $149 \mathrm{C}$ & $9.4 \mathrm{~B}$ \\
\hline T7 & $42.5 \mathrm{~A}$ & $151 \mathrm{C}$ & $8.8 \mathrm{~B}$ \\
\hline LSD & 0.6379 & 4.3970 & 0.9804 \\
\hline
\end{tabular}

Values sharing same letter $(s)$ are statistically similar at $P=0.05$;

Since mint is a heavy feeder of plant nutrients and takes up substantial quantities of N, P and K (Yadav et al., 1983, Patra et al., 2002). The maximum plant height in T7 might be due to appropriate doses of NPK for mint plant. Data (Table 2) showed that higher dose of NPK fertilizers alone was more effective than combined application with FYM.

However, the production of more leaves with combined application of NPK fertilizers and FYM might be due to reason that higher concentration of nitrogen has tendency to increase cell number with an overall increased in leaf production (Bijimol and Singh, 2001). Moreover, FYM due to its capacity to supply macro as well as micronutrients can supplement the nutritional requirements of the mint plants which resulted in better vegetative growth. The result (Table 2) showed that application of NPK along with FYM has a better effect on vegetative growth of plants as they promote the development of leaves and hasten the maturity of plants with higher rate of cell multiplication and differentiation which resulted in better vegetative growth (Belorkar et al., 1992).

\subsection{Herb Yield (T/Ha)}

The effect of combined and alone application of NPK fertilizers and FYM showed a significant $(\mathrm{p}>0.05)$ improvement in herb yield production over control as presented in Table 3. Results demonstrated that maximum herb yield was 20.96 t/ha observed with T6 where NPK was applied 175:50:50 kg/ha and FYM 6 t/ha while minimum 5.66 t/ha with T1 where no fertilizer and FYM were applied. For optimum production of plant yield, NPK and proper plant growth conditions are essential. In the present study, combined application of NPK fertilizers and FYM, resulted in good production in all treatments due to proper supplied of nutrients and soil conditions conducive for plant growth (Bahadur and Gupta, 1964). Similar results have been reported by Patra et al. (1997), Chattopadhyay and Gupta (1999), Patra et al. (2000); Chand et al. (2001) that combined application of inorganic and organic fertilizers plays a significant role in sustaining and improving crop productivity.

Lower production of herb yield in $\mathrm{T} 0$ is due to unavailability of nutrients for proper production throughout growth period (Chattopadhyay and Gupta, 1999). Moreover, application of FYM before the planting of mint suckers produced a beneficial effect on crop growth (Chand et al., 2004). Because of their availability and capacity to supply macro as well as micronutrients, the farm yard manure, farm residues and other organic materials can supplement the nutritional requirements of the mint plants.

\subsection{Oil Yield (kg/ha)}

The interactive effect of NPK fertilizers and FYM demonstrated that combined application of both fertilizers has more pronounced effect than either alone for production of oil yield as shown in Table 3. Results showed that 
maximum herb yield was $169.08 \mathrm{~kg} / \mathrm{ha}$ measured with T5 where NPK was applied 150:45:45 kg/ha and FYM 8 t/ha while minimum $41.34 \mathrm{~kg} / \mathrm{ha}$ with T1 where no fertilizer and FYM were applied.

It was observed that maximum oil yield was produced in T5 where NPK was applied 150:45:45 kg/ha then start declining. It is due to fact that higher application of $\mathrm{N}$ fertilizers resulted in decreased in oil production as reported by Munsi, (1992). Many scientists have been reported that mint oil yield become reduced at higher rate of $\mathrm{N}$ application (Gulati and Duhan, 1971; Bhardwaj et al., 1979; Humblin, 1985; Munsi, 1992; Patra et al., 1993; Ram et al., 2006). However, lower production of oil yield in T0 is due to unavailability of nutrients for proper production during growth period (Chattopadhyay and Gupta, 1999). Moreover, combined applications of organic and inorganic also improve soil properties and make suitable plant growth conditions (Chand, 1999; Patra et al., 2000).

\subsection{Menthol Contents (\%):}

The interactive effect of NPK fertilizers and FYM demonstrated that combined application of both fertilizers has more pronounced effect than either alone for menthol contents as shown in Table 3.

Table 3

\begin{tabular}{|l|l|l|l|}
\hline Treatment & $\begin{array}{l}\text { Herb Yield } \\
\text { (t/ha) }\end{array}$ & Oil Yield (kg/ha) & Menthol Contents $(\%)$ \\
\hline T1 & $5.66 \mathrm{E}$ & $41.34 \mathrm{G}$ & $1.00 \mathrm{G}$ \\
\hline T2 & $9.53 \mathrm{D}$ & $80.96 \mathrm{~F}$ & $1.52 \mathrm{~F}$ \\
\hline T3 & $10.42 \mathrm{D}$ & $96.91 \mathrm{E}$ & $3.03 \mathrm{E}$ \\
\hline T4 & $14.56 \mathrm{C}$ & $151.07 \mathrm{C}$ & $3.77 \mathrm{D}$ \\
\hline T5 & $20.87 \mathrm{~A}$ & $169.08 \mathrm{~A}$ & $4.55 \mathrm{~B}$ \\
\hline T6 & $20.96 \mathrm{~A}$ & $165.59 \mathrm{~B}$ & $5.95 \mathrm{~A}$ \\
\hline T7 & $18.13 \mathrm{~B}$ & $139.63 \mathrm{D}$ & $4.28 \mathrm{C}$ \\
\hline LSD & 1.0114 & 1.2946 & 0.0316 \\
\hline
\end{tabular}

Values sharing same letter( $(s)$ are statistically similar at $P=0.05$;

Results showed that maximum menthol contents were 5.95\% measured with T6 where NPK was applied 175:50:50 $\mathrm{kg} / \mathrm{ha}$ and FYM 6 t/ha while minimum $1 \%$ with T1 where no fertilizer and FYM were applied. Combined application of inorganic and organic fertilizer significantly influenced the $\mathrm{N}$ and $\mathrm{P}$ which resulted in more oil yield and menthol contents production (Patra et al., 2000 and Chand et al., 2001). Similar results had been reported by Chand (1999) that a combined application (FYM 6.7 t/ha and NPK 133:40:40 kg/ha) proved to be best for menthol contents production in Japanese mint. However, lower production of herb yield in T0 is due to unavailability of nutrients for proper production during growth period (Chattopadhyay and Gupta, 1999; Anwar et al., 2010).

Moreover, combined applications of fertilizer and organic residues have greater affect on improved mint oil yield (Patra et al., 2000; Chand et al., 2001). The application of farm yard manure (FYM) before the planting of mint suckers produce a beneficial effect on crop growth (Chand et al., 2004). Because of their availability and capacity to supply macro as well as micronutrients, mint plants perform better and resulted in more oil and menthol contents production.

In addition, combined applications of organic and inorganic also improve soil properties and make suitable plant growth conditions (Chand, 1999; Patra et al., 2000).

\section{CORRELATION BETWEen HERB YIELd AND OIL YIELD}

A positive correlation was observed between Herb Yield and Oil Yield as shown in figure. Data demonstrated that with increased in herb yield, oil yield was increased linearly. With one unit increased in herd yield, the oil yield was increased by a factor of 12.84. However, herb yield and oil yield was maximum with combined application of NPK and FYM. It is due to fact that higher application of $\mathrm{N}$ fertilizers resulted in decreased in oil production as reported by Munsi, (1992). Many scientists have been reported that mint oil yield become reduced at higher rate of $\mathrm{N}$ application (Gulati and Duhan, 1971; Bhardwaj et al., 1979; Humblin, 1985; Munsi, 1992; Patra et al., 1993; Ram et al., 2006). Further, it might be due to the fact that appropriate doses are associated with vegetative growth. In 
addition, FYM has a capacity to supply macro as well as micronutrients which can supplement the nutritional requirements of the mint plants which resulted in better vegetative growth.

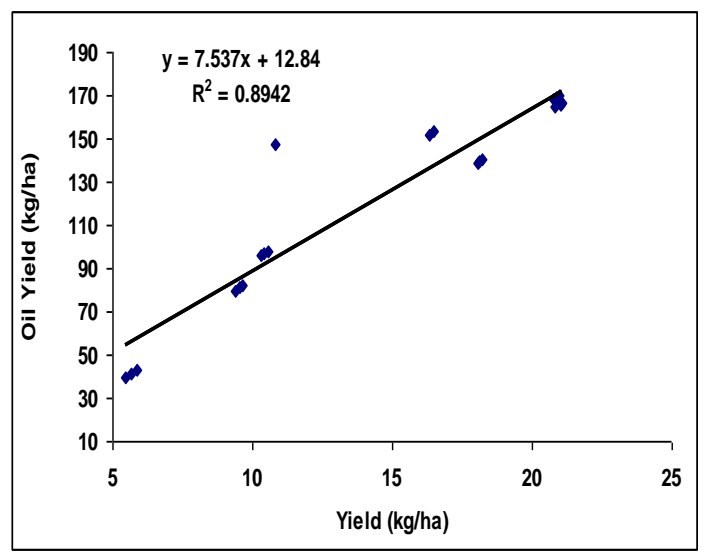

\section{CORRELATION BETWEEN OIL YIELD AND MENTHOL CONTENTS}

A negative correlation was observed between Herb Yield and Oil Yield as shown in figure. Data demonstrated that with increased in oil yield, menthol contents was decreased linearly. With one unit increased in oil yield, menthol contents were decreased by a factor of 0.599 . Many scientists have been reported that mint oil yield become reduced at higher rate of N application (Gulati and Duhan, 1971; Bhardwaj et al., 1979; Humblin, 1985; Munsi, 1992; Patra et al., 1993; Ram et al., 2006). Mahmoud and Younis (2009) found that essential oil yield increased with the corresponding increased in NP fertilizers rates from 75:50 to 100:75 kg/ha. Moreover, combined applications of fertilizer and organic residues have greater affect on improved mint oil yield (Patra et al., 2000; Chand et al., 2001). The application of farm yard manure (FYM) before the planting of mint suckers produce a beneficial effect on crop growth (Chand et al., 2004). Because of their availability and capacity to supply macro as well as micronutrients, mint plants perform better and resulted in more oil and menthol contents production. In addition, combined applications of organic and inorganic also improve soil properties and make suitable plant growth conditions (Chand, 1999; Patra et al., 2000).

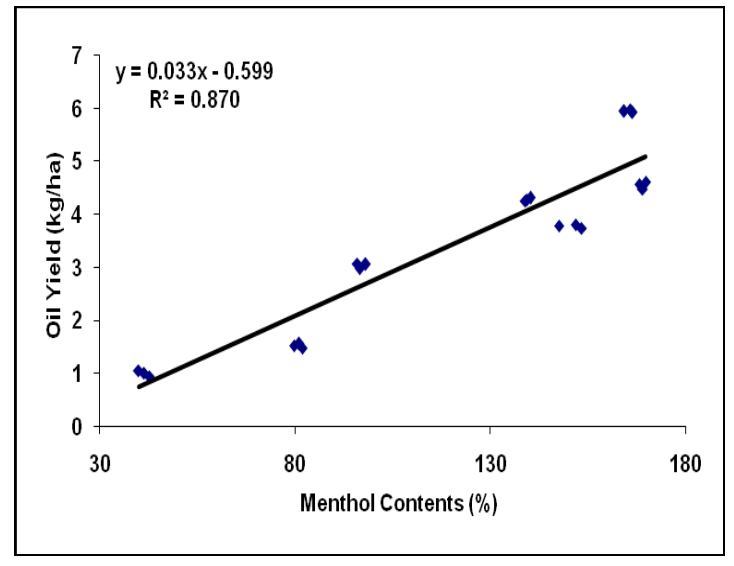

VI. CONCLUSION

Above mentioned facts revealed that for optimum production of plant yield, NPK and proper plant growth conditions are essential. In the present study, combined application of NPK fertilizers and FYM resulted in good production in T5 and T6 due to proper supplied of nutrients and soil conditions conducive for plant growth.

\section{REFERENCES}

[1] Anwar, F., A.I. Hussain, S.T. H. Sherazi and M.I. Bhanger. 2009. Changes in composition and antioxidant and antimicrobial activities of essential oil of fennel (Foeniculum vulgare Mill.) fruit at different stages of maturity. Journal of Herbs, Spices and Medicinals Plants, 15: 1-16. 
[2] Anwar, M., S. Chand and D.D. Patra. 2010. Effect of graded levels of NPK on fresh herb yield, oil yield and oil composition of six cultivars of menthol mint (Mentha arvensis L.). Indian J. Natural Product and Resources, 1: $74-79$.

[3] Belorkar. P.V., B. N. Patel., V. J. Golliwar and A. J. Kohtare. 1992. Effect of nitrogen levels and spacing on growth, flowering and yield of African marigold. J.Soil and Crop, 2:62-64

[4] Bijimol, G and A. K.Singh. 2001. Effect of spacing and nitrogen on flowering, flower quality and post-harvest life of gladiolus. J. App.Hort., 3(1):48-50.

[5] Bruneton, J. 1995. Pharmacognosy, Photochemistry, Medicinal Plants. Lavoisier Publ. Londres, New York, Paris, 405466.

[6] Chand, S. 1999. Integrated nutrients management for sustaining crop productivity and soil fertility in Japanese mint (Mentha arvensis L.) based cropping system. Thesis submitted to Dr. B.R. Ambedkar, University, and Agra, India.

[7] Chand, S., M. Anwar and D. D. Patra. 2001. Influenced of combined application of farm yard manure and inorganic fertilizers on herb, essential oil yield and nutrients accumulation in menthol mint (Mentha arvensis). J. Med. Arom. Plants Sci., 23: 29-34.

[8] Chand, S. N. K. Patra, M. Anwar and D. D. Patra. 2004. Agronomy and uses of Menthol mint (Mentha arvensis) - Indian perspective. Proc. Indian Natl. Sci. Acad., 3: 269-297.

[9] Chattopadhyay, A. and N. Gupta. 1999. Integrated nutrients management in menthol mint cultivation utilizing mint residue fertilizer. J. Med. Arom. Plant Sci., 21:1058-1063.

[10] Clark, G.S. 1998. An aroma chemical profi le: Menthol. Perfum. Flavor, 23:33-46.

[11] Dorman, H. J., M. Kosar, K. Kahlos, Y. Holm and R. Hiltunen. 2003. Antioxidant Prosperities and composition of aqueous extracts from Mentha species, hybrids, varieties and cultivars. J. Agri. and Food Chem., 51:4563-4569.

[12] Guenther, E., 1964. The Essential Oils of Plant Family Labiatae, Vol. III, 5th Revised Ed.,Van D. Nostrand Co. Inc., New York. pp: 640-676.

[13] Gupta, R. 1965. Japanese mint-A new industrial crop in India. Indian Perfumal. 9:69-75.

[14] Hammer K, Laghetti G. 2006. Small agricultural islands and plant genetic resources - Le piccole isole rurali italiane. IGVCNR (ed.), Bari, Italy.

[15] Hopkins, W .G. 1997. The essential nutrients elements: Introduction to Plant Physiology. Jhon Willy and Sons.Inc. Pub.P 68-73

[16] Kewalanand, J.N. Singh and C.S. Pandy. 1998. Effect of plant growth regulators on the growth, herbage and oil yield of Japanese mint (Mentha arvensis) and its economics there form. J Med. Arom. Plant Sci., 20: 725-730.

[17] Lawrence, B.M. 2007. Mint: The genus Mentha. CRC Press, Boca Raton, FL.

[18] Munsi, P. S. 1992. Nitrogen and Phosphorus nutrition response in Japanese mint cultivation. Acta Hort., 306:436-443.

[19] Ohloff, G. 1994. Scent and fragnance springer-verlag New York.

[20] Ozguven, M. and S. Kirici. 1999. Research on yield, essential oil, contents and components of mint (Mentha) Species in different ecologies. Turk J. Agric. For. 23: 465-472.

[21] Patra, D.D. 2008. Essential oil Industries: Problems and opportunities. Ads. 11th International Symposium on Natural product chemistry, University of Karachi, Pakistan, 29 October-01November. P-9.

[22] Patra, D.D., M. Anwar and S. Chand. 2000. Integrated nutrient management and waste recycling for restoring soil fertility and productivity in Japanese mint (Mentha arvensis) and mustard (Brassica juncea) sequence in Utter Pardesh, India. Agric Ecosys Environ., 80: 267-275.

[23] Patra, D.D., M. Anwar, S. Chand, U. Kiran, D.K. Rajoput and S. Kumar. 2002. Nimin and Mentha spicata oil as nitrification inhibitor for optimum yield of Japanese mint (Mentha arvensis). Commun Soil Sci. Plant Anal., 33: 451-460.

[24] Ram, D., R. Muni and R. Singh. 2006. Optimization of water and nitrogen application to menthol mint (Mentha arvensis) through sugarcane trash mulch in a sandy loam soil of semi-arid sub-tropical climate. J. Bio. Tec., 97: 886-893.

[25] Ram, M., D. Ram and S.K. Roy. 2003. Effect of an organic mulching on fertilizers nitrogen use efficiency and herb and essential oil yields in geranium (Pelargonium graveolens). Bioresour. Technol. 87:273-278.

[26] Shinwari, Z.K., A.A. Khan and T. Nakaike, 2004. Medicinal and useful plants of District Swat. WWFPakistan.

[27] Singh, K.M., and S.S. Saini. 2008. Planting date, mulch, and herbicide rate effects on the growth, yield, and physiochemical properties of menthol mint (Mentha arvensis). Weed Technol., 22: 691-698..

[28] Steel, R.G.D., J.H. Torrie and D.A. Dickey. 1997. Principles and procedures of statistics. P.172-177. A biometrical approach. (3rd Ed.). McGraw Hill book Co., Inc. New York, NY, USA.

[29] Weier, T. E., C.R. Stocking., M.G. Barbour and T.L. Rost. 1982. Soil and Mineral Nutrition: Botany. Jhon Wiley and Sons. Inc.pp.208-213

[30] Yadav. R.L., M. Rakesh and M. Ram. 1983. Yield and quality of essential oil of Japanese mint as affected by N rayes and row spacing. Madras Agric J., 70: 454-457.

[31] Yadav.R.L., S.R. Prasad, R. Singh and V.K. Srivastava. 1994. Recycling sugarcane trash to conserve soil organic carbon for sustaining yield of successive ratoon crops in sugarcane. Bioresour. Technol., 49:231-235. 